УДК 811.161.2’276.6]:81’243

\title{
РОБОТА 3 ТЕКСТАМИ ФАХОВОГО СПРЯМУВАННЯ ПІД ЧАС НАВЧАННЯ УКРАЇНСЬКОЇ МОВИ ЯК ІНОЗЕМНОÏ
}

\section{Світлана Бузько}

\author{
Криворізький державний педагогічний університет \\ Kryvyi Rih State Pedagogical University \\ пр. Гагаріна, 54,Кривий Ріг, 50086, Україна \\ buzko.svitlana2408@gmail.com
}

\begin{abstract}
Бузько С. Робота $з$ текстами фахового спрямування під час навчання української мови як іноземної

У статті наведено приклади роботи з текстами фахового спрямування під час викладання української мови як іноземної у закладах вищої освіти педагогічного профілю. Тематика текстів розрахована на студентів природничого, фізико-математичного і географічного факультетів. У розвідці наголошено, що на заняттях 3 української мови як іноземної студентиіноземці, які здобувають вищу педагогічну освіту за різними спеціальностями, обов'язково мають працювати з текстами фахового спрямування. Це допоможе іноземним студентам засвоїти певну кількість лексичних одиниць i синтаксичних конструкцій, потрібних для вивчення низки спеціальних дисциплін (біології, хімії, фізики, астрономії, географії тощо) і здобуття вищої педагогічної освіти. Така робота насамперед має на меті підготувати студентів-іноземців до подальшого сприйняття й розуміння фахової літератури.
\end{abstract}

Ключові слова: українська мова як іноземна, тексти фахового спрямування, мовна підготовка.

Бузько С. Работа с текстами профессиональной направленности во время преподавания украинского языка как иностранного

В статье наведены примеры работы с текстами профессиональной направленности во время преподавания украинского языка как иностранного в заведениях высшего образования педагогического профиля. Тематика текстов рассчитана на студентов естественного, фізико-математического и географического факультетов. В работе акцентировано, что на занятиях по украинскому языку как иностранному студенты-иностранцы, которые получают высшее педагогическое образование по разным спеціальностям, обязательно должны работать с текстами профессиональной направленности. Это поможет иностранным студентам освоить определенное колличество лексических единиц и синтаксических конструкций, нужных для изучения 
ряда специальных дисциплин (биологии, химии, географии, физики, астрономи и др.) и получения высшего педагогического образования. Такая работа прежде всего должна подготовить студентов-иностранцев к дальнейшему восприятию и пониманию профессиональной литературы.

Ключевые слова: украинский язык как иностранный, тексты профессиональной направленности, языковая подготовка.

Buzko S. Work with texts of professional orientation while studying Ukrainian as a foreign language

The article gives examples of work with the texts of professional direction during the teaching of the Ukrainian language as a foreign language in higher educational institutions of the pedagogical profile. The subjects of texts are intended for students of natural sciences, physics and mathematics and geography faculties. The author emphasizes foreign students receiving higher pedagogical education in different specialties must necessarily work with texts of professional orientation during Ukrainian language classes as foreign language. This will help foreign students to acquire many lexical units and syntactic constructions, which are necessary for studying of special disciplines (biology, chemistry, physics, astronomy, geography, etc.) and getting higher pedagogical education. First of all, this work is aimed at preparing foreign students for further perception and understanding of professional literature.

It is emphasized that the methodology of teaching Ukrainian as a foreign language differs fundamentally from the methodology of teaching Ukrainian as a mother tongue. Such a difference is determined by a number of actual linguistic, linguo-didactic and psychological factors. Despite many textbooks and study guides for foreign students have been made, the question of finding methods of teaching Ukrainian as a foreign language remains relevant. Consequently, the relevance of the article is determined by the latest requirements aimed at improving the modern national education system in general and the language training of foreign students in particular.

Key words: Ukrainian as a foreign language, texts of professional orientation, language training.

\section{Постановка проблеми та її зв'язок із важливими} науковими завданнями. Нині велика кількість іноземних громадян здобуває вищу освіту в навчальних закладах України. Тому не викликає заперечень той факт, що існує нагальна потреба в розробленні методичних засад вивчення української мови як іноземної. Цілком зрозуміло, що методика навчання української мови як іноземної суттєво відрізняється від методики навчання української мови як рідної. Така різниця визначається низкою власне лінгвістичних, лінгводидактичних та психологічних чинників. Попри те, що укладено низку 
підручників та навчальних посібників для студентів-іноземців, залишається актуальним питання пошуку методів і прийомів викладання української мови як іноземної; також потребують доопрацювання програми та освітні стандарти загалом. “До того ж, - як зауважують лінгводидакти, - українська мова як іноземна ще не посіла надійного місця поряд із парадигмою понять, уже затверджених законодавчими актами: українська мова як державна, українська мова як рідна, українська мова як нерідна" [Bakum / Бакум 2010 : 227]. Отже, актуальність пропонованої статті визначається новітніми вимогами, спрямованими на вдосконалення сучасної національної системи освіти загалом та мовної підготовки іноземних студентів зокрема.

Аналіз останніх досліджень та публікацій. Сучасна лінгводидактика пропонує різні методи та прийоми навчання української мови як іноземної. Розроблено "Концепцію мовної підготовки іноземців у ВНЗ України”, у якій визначена головна мета мовної підготовки іноземних громадян - забезпечення комунікативних умінь і навичок у різних сферах спілкування: науковій, суспільно-політичній, соціально-культурній, побутовій тощо [Ushakova / Ушакова 2011 : 138]. Г. Строганова, О. Тростинська, Н. Ушакова аналізують загальні концептуальні підходи до вивчення української мови як іноземної [Strohanova / Строганова 2008 : 173-179; Ushakova / Ушакова 2014 : 12-21]. Різні аспекти викладання української мови як іноземної висвітлюють у своїх працях 3. Бакум, I. Дирда, Т. Сфімова, С. Костюк, А. Кулик, Т. Лагута, О. Коваленко, Л. Олійник та ін. Граматичні й текстові матеріали для роботи 3 іноземними студентами представлено, зокрема, в дослідженнях таких учених, як Л. Азарова, С. Воробйова, І. Зозуля, Р. Кривко, Н. Лисенко, Т. Мелкумова, І. Майданюк, С. Світлична й ін.

У розвідках Т. Гаврющенко, Л. Суботи, Н. Філяніної розробляється принцип професійної спрямованості у навчанні студентів-іноземців, який полягає в оволодінні професійно зорієнтованими знаннями, уміннями й навичками. Значну роль у цьому відіграє робота 3 текстами фахового спрямування, що сприяє формуванню системи знань, умінь і навичок, необхідних 
для подальшого навчання й ознайомлення з вузькоспеціальними дисциплінами.

Мета пропонованої розвідки - наведення прикладів роботи 3 текстами фахового спрямування під час навчання української мови як іноземної в закладах вищої освіти педагогічного профілю. Тексти розраховані на студентів природничого, фізико-математичного і географічного факультетів.

Виклад основного матеріалу дослідження. На заняттях з української мови як іноземної студенти-іноземці, що здобувають вищу педагогічну освіту 3 різних спеціальностей, обов'язково мають працювати 3 текстами фахового спрямування. Це допоможе іноземним студентам засвоїти певну кількість лексичних одиниць i синтаксичних конструкцій, потрібних для вивчення низки спеціальних дисциплін (біології, хімії, фізики, астрономії, географії тощо) i здобуття вищої педагогічної освіти. Така робота насамперед має на меті підготувати студентів-іноземців до подальшого сприйняття й розуміння фахової літератури.

Текст 1 пропонуємо для студентів-іноземців, які навчаються на природничому та фізико-математичному факультетах.

Усе́, цио нас ото́чує, склада́ється з мате́ріï. Мате́рія - иุe речовина́, з яко́ї склада́ються всі предме́ти. Вона́ форму́є весь навко́лишній світ. Мате́рія склада́ється з моле́кул.

Моле́кула - цуе ду́же мале́нька (мікроскопічна) части́нка речовини́. Моле́кули постїйно ру́хаються. Якщуо зб́льшується температу́ра речовини́, то збі́льшується шви́дкість ру́ху моле́кул. Моле́кули склад́ються з а́томів.

А́том - цее найме́нша, хімі́чно неподі́льна части́нка речовини́. А́томи пос́нуються і утво́рюють моле́кули. У це́етрі бу́дь-яко́го а́тома знахо́диться ядро́. Ядро́ а́тома склада́ється з прото́нів та нейтро́нів. Навко́ло цьього́ ядра́ оберта́ються електро́ни. О́тже, електро́ни, прото́ни $i$ нейтро́ни - цуе елемента́рні части́нки, з яки́х склада́ється а́том.

Дифу́зія - чее процее́с взаємного прони́кнення моле́кул або а́томів однієї речовини́ по́між моле́кул або́ а́томів і́ншої

(c) С. Бузько, 2019. 
речовини́. Напри́клад, поши́рення за́пахів - цее дифу́зія (перемі́шування) га́зів.

Після читання тексту слід провести бесіду за змістом, аби з'ясувати, якою мірою іноземні студенти зрозуміли прочитане. Орієнтовний перелік запитань за змістом тексту: Що таке матерія? 3 чого складається матерія? Що таке молекула? 3 чого складаються молекули? 3 яких частинок складаються атоми? Що таке дифузія? Які вам відомі приклади дифузії?

Після усної бесіди за змістом прочитаного студентам запропоновано письмові завдання, спрямовані на перевірку розуміння тексту й закріплення нових відомостей. Наприклад, студенти повинні закінчити речення й записати їх у зошити: 1. Матерія формує .... 2. Матерія складається з .... 3. Молекули складаються з .... 4. У центрі атома .... 5. Навколо ядра атома обертаються .... Або ж замість крапок необхідно вставити потрібні слова (частинка, ядро, протони, нейтрони, речовина, електрони): 1. Матерія - че ..., 3 якої складаються всі предмети. 2. Молекула - це мікроскопічна ... речовини. 3. ...- ие частинка молекули. 4. У центрі атома знаходиться ... 5. Елементарні частинки атома - ие ...

Другий блок завдань спрямований на повторення деяких відомостей із граматики, на актуалізацію вже набутих умінь і навичок. Наприклад, необхідно утворити форму множини від поданих слів (молекула, атом, речовина, нейтрон, протон, електрон, частинка). Або слова в дужках потрібно поставити у відповідній граматичній формі: 1. Фізика (вивчати) речовини. 2. Речовина - ие вид (матерія). 3. Речовини (складатися) 3 молекул. 4. Молекули (ділитися) на атоми. 5. Молекули складаються з (атоми). 6. (Центр) атома знаходиться ядро. 7. Навколо (ядро) обертаються електрони.

Текст 2, як і попередній, пропонуємо для студентів, які навчаються на природничому та фізико-математичному факультетах. Він стосується деяких елементарних понять, що вивчають не лише в межах природничих дисциплін, але й у курсі фізики).

Усі́ предме́ти склада́ються 3 пе́вних матеріа́лів. матеріа́л - ие фо́рма мате́рії. Ма́йже всі матеріа́ли 
виготовля́ють із їнших матеріа́лів. Напри́клад, бензи́н отри́мують із на́фти; залі́зо виготовля́ють із руди́; папі́p виготовля́ють із дерева.

Матеріа́ли, які́ ма́ють приро́дне похо́дження, - це перви́нна мате́рія. Напри́клад, дере́ва, з яки́х виготовля́ють папі́p i ме́блі, - це перви́нна мате́рія. Різномані́тні мінера́ли, залізна руда́-теж перви́нна матерія.

Де́які матеріа́ли склада́ються з волокна́. Волокно́ - ие до́вгий і тонки́й, як волоси́на, матеріа́л. Воло́кна бува́ють рі́зних ви́дів: росли́нного похо́дження, твари́нного похо́дження $i$ итуичні.

Воло́кна росли́нного похо́дження - цее, напри́клад, баво́вна. Воло́кна твари́нного похо́дження - це во́вна, шовк. Воло́кна росли́нного і твари́нного похо́дження - це натура́льні воло́кна.

Шту́чні воло́кна (ненатура́льні, синтети́чні) отри́мують із проду́ктів хімі́чної переро́бки різзних матеріа́лів. До шту́чних нале́жать воло́кна таки́х матеріа́лів, як віско́за, нейло́н, поліетиле́н та їнші.

Після того, як студенти прочитають текст (бажано не один, а кілька разів), вони дають усні відповіді на запитання: 3 чого складаються всі предмети, які нас оточують? Що таке матеріал? Із чого отримують бензин? Із чого виготовляють nапір? Із чого виготовляють залізо? Первинна матерія - це щзо? Які бувають волокна?

Завдання, що передбачають усні відповіді, варто поєднувати 3 письмовими завданнями за змістом тексту. Наприклад, закінчити речення і записати їх у зошити: 1. Первинна матерія - це матеріали, які ... 2. Натуральні волокна - це .... 3.Із продуктів хімічної переробки різних матеріалів отримують .... 4. Бавовна, вовна, шовк - ие .... 5. Нейлон $і$ віскоза - це .... Або замість крапок вставити потрібні слова: 1. Вовна і шовк - це волокна ... походження. 2. Бавовна це волокно ... походження. 3. Штучні волокна-иче ... волокна.

Як уже зазначалося, завдання за змістом тексту бажано поєднувати із завданнями 3 граматики української мови, аби актуалізувати вже набуті іноземними студентами знання, уміння й навички. Однак лексичний матеріал для таких завдань ми

(c) С. Бузько, 2019. 
пропонуємо брати з опрацьованого тексту, що сприяє кращому запам'ятовуванню нових слів і понять. Наприклад, студенти повинні утворити форму множини від поданих слів (волокно, предмет, матеріал, дерево, продукт, мінерал) або визначити граматичний рід поданих іменників (матерія, матеріал, волокно, форма, бензин, нафта, руда, дерево, вовна, шовк, папір, бавовна, віскоза, нейлон). Або з поданих слів студенти мають скласти речення, поставивши всі слова увідповідній граматичній формі: 1. Усі предмети / складатися / матеріали. 2. Бензин / отримувати / нафта. 3. Папір / виготовляти / дерево. 4. Залізо / виготовляти / руда.

Текст 3 пропонуємо для студентів-іноземців, які навчаються на географічному факультеті.

\section{Центра́льна А́зія.}

Центра́льна А́зія - це части́на А́зї, яка́ ма́є ви́хід до Каспїйського мо́ря. На терито́рї Центра́льної А́зї розташо́вані такі́ крайни: Узбекиста́н, Киргизста́н, Таджикиста́н, Казахста́н і Туркменіста́н.

Бі́льша части́на терито́рії Центра́льної А́зї- че пусте́лі; тому́ клі́мат тут перева́жно посу́шливий. Бага́то о́падів випада́є ті́льки в го́рах. Го́ри розташо́вані на пі́вдні Центра́льної А́зї; вони́ займа́ють 1/3 части́ну регіо́ну. Найбїльші гірські́ маси́ви Центра́льної А́зї - ие Памір, ТяньШа́нь, Копетда́z.

Центра́льна А́зія ма́є значні́ запа́си таки́х кори́сних копа́лин, як приро́дний газ, на́фта, кам'яне́ вугі́лля, залі́зна руда́. Бі́льша части́на приро́дного га́зу, яки́й спожива́є Украйна, імпорту́ється з Туркменіста́ну.

Головні́ річки́ Центра́льної А́зї-Аму́дар'я і Си́рдар'я; ие основні во́дні арте́рії регіо́ну. Водо́ю иих річо́к зро́шуються зе́млі, на яки́х виро́щують баво́вну, о́вочі, фру́кти, башта́нні культу́ри (кавуни́ й ди́ні), виногра́д.

Найбільші міста́ Центра́льної А́зї-це Алмати́, Ташке́нт, Душанбе́, Бішке́к, Ашхаба́д. Густота́ насе́лення тут ма́йже 200 чоловік на 1 квадра́тний кіломе́тр. Пусте́лі ци високогір'я засе́лені ма́ло. 
Після читання тексту студентам традиційно бесідують за змістом прочитаного: Які́ країни розташо́вані на терито́рії Центра́льної А́зї? Яку́ части́ну Центра́льної А́зї займа́ють го́ри? Які́ ви зна́єте гірські́ маси́ви Центра́льної А́зї? Що виро́шують на зе́млях Центра́льної А́зії? Які кори́сні копа́лини є в Центра́льній А́зї? Назві́mь найбі́льші міста́ Центра́льної А́зї.

Оскільки більшість іноземних студентів, які здобувають нині вищу педагогічну освіту у КДПУ, - це громадяни Туркменістану, питання за текстом можуть стосуватися також безпосередньо географії цієї країни: Які з названих у тексті гірських масивів знаходяться на території Туркменістану? Які ви ще можете назвати великі міста Туркменістану, крім Ашхабада? Яких корисних копалин найбільше в Туркменістані? Які пустелі знаходяться на територіі Туркменістану?

Наступний етап роботи над цією темою - читання діалогу й обговорення нової інформації. Студент повинні прочитати діалог і розказати, що нового вони дізналися про Середню Азію:

- Приві́m, Іхла́се. Яка́ те́ма рефера́my, яки́ŭ ти за́раз númeш?

- Приві́m, Шагелді́. Я готу́ю рефера́m про країни Центра́льної А́зї̈.

- Це та части́на А́зї, де знахо́диться Ара́льське мо́ре?

- Так, його́ ше назива́ють соло́ним о́зером. Розташо́ване воно́ на терито́рії Казахста́ну та Узбекиста́ну. пересо́хло?

- Чи пра́вда, що Ара́льське мо́ре ма́йже по́вністю

- На жаль, так. 3 а оста́нні 40-50 ро́ків рі́вень Ара́льського мо́ря си́льно зни́зився; за́раз воно́ практи́чно по́вністю пересо́хло. Ара́л - ие регіо́н екологічного ли́ха, томи́ щчо морська́ фло́ра і фа́уна там поступо́во зника́ють.

Після цього студентам пропонуємо переписати речення, вставивши потрібні слова: 1. Центра́льна Азія ма́є ви́хід до (Ара́льського / Каспійського) мо́ря. 2. Бі́льша части́на терито́рії Центра́льної А́зї- ие (пусте́лі / го́ри). 3. Клі́мат у Центра́льній Азї в основно́му (посу́шливий / воло́гий). 4. Аму́дар'я $і$ Си́рдар'я - це (найме́нші / найбі́льші) річки́ Центра́льної А́зї. 5. Го́ри розташо́вані (на пі́вдні / на пі́вночі) Центра́льної А́зї.

(C) С. Бузько, 2019. 
Наступні завдання пов'язані 3 повторенням вивчених раніше відомостей із граматики, з актуалізацією вже набутих умінь і навичок. Наприклад, студенти повинні подані слова та словосполучення поставити у форму родового відмінка за таким зразком: (Що?) Центральна Азія - (Чого?) Центральної Азії): Ара́льське мо́ре; морська́ фло́ра і фа́уна; вели́кий регіо́н; гірськи́й маси́в; екологі́чна катастро́фа; посу́шливий клі́мат; соло́не о́зеро; вели́кі міста́; найбі́льші річки́. Звичайно, під час виконання цього завдання іноземним студентам важко обійтися без допомоги викладача; доводиться постійно акцентувати на різних формах граматичного роду, а також на формах однини та множини.

Текст 4 розрахований на студентів, які навчаються на природничому факультеті.

Організмм люди́ни. О́ргани й фізіологі́чні систе́ми.

організм люди́ни - це складна́ біологічна систе́ма, до скла́ду якӧї вхо́дять рі́зні о́ргани. О́рган - че части́на ті́ла, яка́ ма́є пе́вне розташува́ння, будо́ву і вико́нує свої фу́нкиї. О́ргани об'є́днуються у фізіологічні систе́ми. Фізіологічна систе́ма суку́пність о́рганів, які́ забезпе́чують пере́біг найважливі́их житте́вих проце́сів.

Напри́клад, систе́ма травлення склада́ється з таки́х о́рганів, як ротова́ порожни́на, зу́би, гло́тка, стравохі́, илу́нок, підшлунко́ва за́лоза, печі́нка, кише́чник. Головне́ завда́ння иієї систе́ми - перетворитти їжу, яку́ спожива́є люди́на, на кори́сні речовйни, зда́тні засвӧїтися органі́змом. Видільна́ систе́ма відповіда́є за ви́ведення з організму проду́ктів о́бміну і різзнх шкідли́вих речови́н. Ди́хальна систе́ма люд́ни предста́влена таки́ми о́рганами, як носова́ порожни́на, горта́нь, трахе́я, бро́нхи, леге́ні. Ця систе́ма доставля́є до кровоно́сних суди́н ки́сень, яки́й потрібен організзму для ви́роблення ене́ргіï. Опо́рнорухова́ систе́ма - ие кістки́ і м'я́зи; вона́ відповіда́є за ру́хи ті́ла $i$ за́хист вну́трішніх о́рганів. До скла́ду нерво́вої систе́ми вхо́дять не́рви, нерво́ві вузли́, спинни́й та головни́й мо́зок; ия систе́ма відповіда́є за керува́ння всім організмом за допомо́гою нерво́вих і́мпульсів. Ендокри́нна систе́ма регулю́є дія́льність організму за допомо́гою гормо́нів. Репродукти́вна систе́ма 
включа́є стате́ві о́ргани, які́ забезпе́чують проче́сси розмно́ження люди́ни. Іму́нна систе́ма забезпе́чує за́хист організму від шкідли́вих бакте́рій та ві́русів. Ду́же важли́вою $є$ кровоно́сна систе́ма, до скла́ду яко́ï вхо́дять такі о́ргани, як се́рие, арте́рії, ве́ни, капіля́ри. Ця систе́ма перено́сить ки́сень, вуглеки́слий газ, мінера́льні та органі́чні речови́ни.

Спїльна $і$ зла́годжена взаємодія фізіологічних систе́м забезпе́чує робо́ту всього органі́зму.

Після читання тексту студентам традиційно запропоновано бесіду за змістом прочитаного. Орієнтовний перелік запитань: Які ви знаєте фізіологічні системи організму людини? 3 яких органів складається система травлення? Яку функцію виконує в організмі людини дихальна система? За щчо відповідає опорно-рухова система? За щуо відповідає нервова система? Що входить до ії складу? Яка функиія ендокринної системи? Що забезпечує репродуктивна система? Яку функиію виконує імунна система?

Наступне завдання спрямоване на перевірку розуміння тексту. Замість крапок необхідно вставити потрібні слова (завдання виконується письмово): 1. Органи об'єднуються у .... 2. Фізіологічні системи складаються з .... 3. Органи системи травлення: .... 4. Органи дихальної системи: .... 5. Органи кровоносної системи: ....

Наступним етапом роботи над пропонованою темою $\epsilon$ читання діалогу й обговорення прочитаного. Студенти мають прочитати діалог і розказати, про які ще фізіологічні системи організму людини вони дізналися:

-Приві́m, Андрі́ю. Яка́ те́ма насти́пного заня́ття 3 анато́міï?

-Приві́m, Богда́не. На насту́пне заня́ття з анато́мії тре́ба, підготува́ти інформа́цію про сенсо́рні систе́ми органі́зму люди́ни.

- Ти вже ви́вчив цей матеріа́л?

-Так, у підру́чнику я вже прочита́в, щзо складови́ми сенсо́рних систе́м є о́ргани чуття́ - иее зір, слух, смак, до́тик, рівнова́zа.

() С. Бузько, 2019. 
- То́бто сенсо́рні систе́ми відповіда́ють за надхо́дження інформа́ції із зо́внішнього середо́вищза?

-Так, і провідну́ роль се́ред сенсо́рних систе́м людсько́го організму відіграє зір. А́же основну́ части́ну інформа́иії про навко́лишній світ люди́на отри́мує че́рез о́ргани зо́ру. Проте́ інші фізіологічні систе́ми є теж дуюе важли́вими для життя́ люди́ни.

Як i під час роботи 3 іншими текстами фахового спрямування, другий блок завдань спрямований на повторення i закріплення відомостей із граматики української мови. Наприклад, задля повторення особливостей відмінювання іменників і прикметників різних граматичних родів студенти повинні провідміняти подані словосполучення (дихальна система, людський організм, головне завдання) за таким зразком:

Називний відмінок (хто? щио?) - опоно-рухова система .

Родовий відмінок (кого? чого?) - опорно-рухової системи.

Давальний відмінок (кому? чому?) - опорно-руховій системі.

Знахідний відмінок (кого? щчо?) - опорно-рухову систему.

Орудний відмінок (ким? чим?) - опорно-руховою системою.

Місцевий відмінок (у кому? у чому?) - в опорно-руховій системі.

Також можна запропонувати виписати з тексту іменники у формі однини та у формі множини; виписати окремо іменники чоловічого, жіночого та середнього родів.

\section{Висновки та перспективи подальших наукових} розвідок. Отже, важливим етапом мовної підготовки іноземних студентів, які навчаються в педагогічних вишах України, $є$ робота 3 текстами фахового спрямування. Це сприяє засвоєнню студентами-іноземцями певної кількості лексичних одиниць і синтаксичних конструкцій, потрібних для вивчення низки спеціальних дисциплін і здобуття вищої педагогічної освіти в Україні. Така робота $є$ невід'ємною складовою підготовки 
іноземних студентів до адекватного сприйняття й розуміння фахової літератури. Подальші наукові розвідки передбачають більш грунтовне вивчення концептуальних підходів, методів та прийомів викладання української мови як іноземної, що сприятиме вдосконаленню процесу мовної підготовки іноземних студентів, які здобувають освіту в закладах вищої освіти України.

\section{Література}

1. Бакум 3. П. Українська мова як іноземна: лінгводидактичні проблеми. Філологічні студії : Науковий вісник Криворізького державного педагогічного університету. Кривий Ріг, 2010. Вип. 5. С. 226-232.

2. Строганова Г. Концептуальні підходи до засвоєння української мови іноземними студентами. Теорія і практика викладання української мови як іноземної : зб. наук. пр. Львів, 2008. Вип. 3. С. 173-179.

3. Ушакова Н. І., Дубічинський В. В., Тростинська О. М. Концепція мовної підготовки іноземців у ВНЗ України. Викладання мов у вищих навчальних закладах на сучасному етапі. Міжпредметні зв'язки : зб. наук. пр. Харків, 2011. Вип. 19. С. 136-146.

4. Ушакова Н. І., Тростинська О. М. Вивчення української мови студентами-іноземцями : концептуальні засади. Теорія і практика викладання української мови як іноземної : зб. наук. пр. Львів, 2014. Вип. 9. С. 12-21.

\section{References}

1. Bakum Z. P. Ukrayinska mova yak inozemna : lingvodidaktichni problemy. Filolohichni studiyi : Naukovyi visnyk Kryvorizkoho derzhavnoho pedahohichnoho universitetu. Kryvyi Rih, 2010. Vyp. 5. S. 226-232.

2. Strohanova H. Kontseptualni pidhody do zasvoyennya ukrayinskoyi movy inozemnymy studentamy. Teoriya i praktika vikladannya ukrayinskoyi movy yak inozemnoyi : zb. nauk. pr. Lviv, 2008. Vyp. 3. S. 173-179.

3. Ushakova N. I., Dubichynsky V. V., Trostynska O. M. Kontseptsiya movnoyi pidhotovky inozemtsiv u VNZ Ukrayiny. Vykladannya mov u vyshchyh navhcalnyh zakladah na suhcasnomu etapi. Mizhpredmetni zuyazki : zb. nauk. pr. Harkiv, 2011. Vyp. 19. S. 136-146.

4. Ushakova N. I., Trostynska O. M. Vivchennya ukrayinskoyi movy studentamy-inozemtsymi : kontseptualni zasady. Teoriya i praktika vikladannya ukrayinskoyi movy yak inozemnoyi : zb. nauk. pr. Lviv, 2014. Vyp. 9. S. 12-21.

Стаття надійшла до редакиії 29.03.2019 p. Прийнята до друку 07.05. 2019 p. 